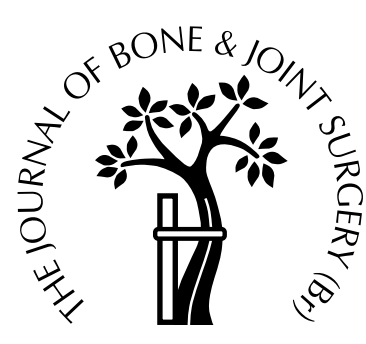

\title{
Cryosurgery for chronic injuries of the cutaneous nerve in the upper limb
}

\author{
ANALYSIS OF A NEW OPEN TECHNIQUE \\ Evan Davies, Derrick Pounder, Sam Mansour, Ian T. A. Jeffery \\ From the Queen Alexandra Hospital, Portsmouth, England
}

W e have treated six patients with chronic pain following nerve injury using a cryosurgical probe. All had a significant return of hand function and improvement of pain during a mean follow-up of 13.5 months. Open visualisation of the injured nervous tissue is essential for patients undergoing this technique. Four patients regained normal sensation in the dermatome of the previously injured nerve.

J Bone Joint Surg [Br] 2000;82-B:413-5.

Received 12 May 1999; Accepted after revision 31 August 1999

Injuries of a cutaneous nerve can cause chronic pain which may be resistant to treatment. The management may include the use of tricylic and anticonvulsant drugs and surgical resection with transplantation of nerves into muscle bellies ${ }^{1}$ or intraosseous compartments. ${ }^{2}$ Damage to the superficial radial nerve (SRN) may generate a neuroma, ${ }^{3}$ but this does not need to be present for the nerve to malfunction and cause pain. The results of treatment have been variable.

Hyperalgesia may follow nerve damage in the sensory dermatome supplied by a nerve. Chronic peripheral neuroexcitability results in major disability. Damage to the SRN may cause limitation of function and grip so that the patient may make a considerable effort to protect the affected hand from tactile stimulation using gloves and protective bandages. This may cause restriction of normal social activities and threaten the prospect of employment.

Cryosurgery is currently used in the treatment of malignancy of the liver ${ }^{4}$ and prostate. ${ }^{5}$ This technique has been used on peripheral nerves with success in chronic facial pain, with and without neuromata. ${ }^{6}$ Long-term follow-up of cryosurgery in paroxysmal trigeminal neuralgia has shown considerable relief of symptoms in most patients, but after about four years they may experience some degree of

E. Davies, FRCS Ed, Orthopaedic Specialist Registrar

D. Pounder, FRCA, Consultant Anaesthetist

S. Mansour, MB, ChB, Orthopaedic Associate Specialist

I. T. A. Jeffery, FRCS, Consultant Orthopaedic Surgeon

Queen Alexandra Hospital, Cosham, Portsmouth PO6 3LY, UK.

Correspondence should be sent to Mr E. Davies c/o Mr I. T. A. Jeffery.

(C)2000 British Editorial Society of Bone and Joint Surgery

0301-620X/00/310190\$2.00

VOL. 82-B, No. 3, APRIL 2000 recurrence. Further freezing of the nerves can give as good a result as the primary attempt. The results are an improvement on those of the traditional techniques of injection of alcohol, neurectomy and radiofrequency thermocoagulation. $^{7,8}$ In orthopaedics, cryosurgery has been used in a limited form to treat Morton's neuroma of the foot, using a percutaneous method. ${ }^{9}$

The cryoprobe produces a lowering in temperature by allowing the escape of a pressurised gas through a small orifice which, as it rapidly expands, causes cooling of the tip. The cold tip of the probe then absorbs heat from surrounding tissues to which it is applied causing a localised area of frostbite.

Experimental studies have shown that after cryotherapy of nerves ordered regeneration may occur if the gross architecture of the nerve is maintained. ${ }^{10}$ Cryotherapy causes disintegration of the axon, breakdown of the myelin sheath and Wallerian degeneration. Panaxonal necrosis, with associated Wallerian degeneration, is more likely to occur when repeated freezing of the nerve is interspersed by periods of thawing. Excessive freezing can lead to gross destruction of all tissues, preventing regeneration and producing further neuromata.

The perineurium and epineurium remain intact allowing ordered axonal regeneration. Studies in rats have shown that peripheral cryotherapy has central effects in the dorsal horn of the spinal cord. ${ }^{11}$ The neurotransmitter, substance $\mathrm{P}$ (a nociceptive peptide), is reduced in the dorsal horn of the spinal cord. It therefore appears appropriate to treat patients with disordered nerve regeneration by this technique. We have used this method for chronic pain syndromes in the upper limb which follow injuries to the nerve.

\section{Patients and Methods}

All six patients in this study were referred from the hand clinic to the pain management clinic for assessment before cryosurgery. There were four men and two women with a mean age of 50.5 years (24 to 83). The mean follow-up was 13.5 months (6 to 36). The dominant hand was involved in four. They presented with a history of chronic pain and dysfunction of the hand which had been present for a mean of 24 months after a discrete injury. All had developed pain in a particular dermatome and sensory changes were pres- 
Table I. Details and outcome for the six patients who received cryosurgery

\begin{tabular}{|c|c|c|c|c|c|c|c|c|c|}
\hline Case & Gender & $\begin{array}{l}\text { Age } \\
(\mathbf{y r})\end{array}$ & Aetiology & Symptoms and signs & $\begin{array}{l}\text { Duration of } \\
\text { symptoms before } \\
\text { cryosurgery } \\
\text { (mth) }\end{array}$ & Lesion & $\begin{array}{l}\text { Previous } \\
\text { treatments }\end{array}$ & $\begin{array}{l}\text { Patient } \\
\text { satisfaction }\end{array}$ & Outcome \\
\hline 1 & M & 58 & Accidental laceration & $\begin{array}{l}\text { Pain. Avoiding social } \\
\text { contact and work. Strong Tinel. } \\
\text { Glove worn to protect scar }\end{array}$ & 24 & $\begin{array}{l}\text { SRN and } \\
\text { neuroma }\end{array}$ & $\begin{array}{l}\text { Excision of neuroma } \\
\text { and implantation into } \\
\text { brachioradialis }\end{array}$ & Excellent & $\begin{array}{l}\text { Returned to work. } \\
\text { Normal social contact }\end{array}$ \\
\hline 2 & M & 55 & Post trapeziectomy & $\begin{array}{l}\text { Pain. Decreased sensation. } \\
\text { Interfering with employment }\end{array}$ & 8 & SRN & $\begin{array}{l}\text { Guanethidine } \\
\text { Amitriptyline }\end{array}$ & Good & $\begin{array}{l}\text { No clinical problems. } \\
\text { Occasional pain }\end{array}$ \\
\hline 3 & $\mathrm{~F}$ & 33 & Accidental laceration & $\begin{array}{l}\text { Pain. Severe interference with } \\
\text { hygiene, toilet and dressing } \\
\text { Bandage worn to protect scar }\end{array}$ & 36 & $\begin{array}{l}\text { SRN and } \\
\text { neuroma }\end{array}$ & $\begin{array}{l}\text { Guanethidine } \\
\text { blockade }\end{array}$ & Excellent & $\begin{array}{l}\text { No clinical problems. } \\
\text { Occasional pain on } \\
\text { palpation }\end{array}$ \\
\hline 4 & $\mathrm{~F}$ & 55 & $\begin{array}{l}\text { After DeQuervain's } \\
\text { release }\end{array}$ & $\begin{array}{l}\text { Pain. Severe limitation of hand } \\
\text { function and grip }\end{array}$ & 28 & SRN & $\begin{array}{l}\text { Guanethidine } \\
\text { Tegnetol } \\
\text { TENS }\end{array}$ & Good & $\begin{array}{l}\text { No clinical problems } \\
\text { Normal hand function }\end{array}$ \\
\hline 5 & M & 83 & $\begin{array}{l}\text { Accidental burns } \\
\text { and lacerations }\end{array}$ & $\begin{array}{l}\text { Pain. Unable to flex digits } \\
\text { or grip with hand }\end{array}$ & 24 & Digital nerve & $\begin{array}{l}\text { Guanethidine } \\
\text { blockade }\end{array}$ & Good & $\begin{array}{l}\text { Hand grip and digital } \\
\text { flexion normal. Occasional } \\
\text { discomfort }\end{array}$ \\
\hline 6 & M & 24 & $\begin{array}{l}\text { Digital fractures } \\
\text { and amputations }\end{array}$ & $\begin{array}{l}\text { Severe digital pain and stump } \\
\text { pain. Interfering hygiene } \\
\text { and work }\end{array}$ & 26 & Digital nerve & $\begin{array}{l}\text { Guanethidine } \\
\text { blockade }\end{array}$ & Good & $\begin{array}{l}\text { Hand grip normal. Patient } \\
\text { returned to work as normal }\end{array}$ \\
\hline
\end{tabular}

ent in all. One patient had complete sensory loss before surgery. Most described severe pain as well as paraesthesiae in the sensory distribution of the nerve. Four had a considerable increase in pain when the area of altered sensation was touched. In two patients, this caused them to shun all forms of social and work contact. Those in employment were unable to work or were obliged to alter their work pattern because of their symptoms. Table I gives details of the initial symptoms and aetiology. Four patients had lesions of the SRN and two of a digital nerve. Alternative methods of pain relief such as intravenous sympathetic blockade (guanethidine blocks), transcutaneous nerve stimulators and tricyclic and anticonvulsant agents, had all failed to improve their clinical symptoms (Table I).

Discrete blockade with local anaesthesia around the proximal part of the injured cutaneous nerve, was carried out on at least two occasions. This allowed assessment of relief of pain and improvement in function before cryosurgery. If there was notable relief after this procedure open cryosurgery was carried out on the nerve as a day case under general anaesthesia.

At operation, the damaged nerve was explored using a tourniquet to allow direct visualisation of the nerve tissue or neuroma. If a neuroma was present it was not excised, but the cryotherapy was applied proximal to the lesion. When no obvious neuroma was present the cryotherapy was made well proximal to the original site of injury. In all cases the Spembly cryoprobe was used with nitrous oxide gas as the refrigerant. The tip of the probe measured $2 \mathrm{~mm}$ in diameter. This was placed directly on the nerve for two minutes to allow thorough freezing of the tissue at $-60^{\circ} \mathrm{C}$ (Fig. 1) and then reapplied for a further two minutes after defrosting for 30 seconds. KY jelly was used on the end of the probe to allow good formation of the ice ball across the nerve. Haemostasis was then achieved and the wounds closed normally. Patients were reviewed independently by a 'blinded' orthopaedic specialist registrar at a research clinic. The reviewer was not involved in the treatment or surgery of any patient.

\section{Results}

The patients used a scale of 'excellent', 'good', 'satisfactory', 'poor' and 'unacceptable' to rate their results from the procedure. Two rated their outcome as excellent and four as good. No patient had a poor or unacceptable result. All had found the preoperative injection of $0.5 \%$ Bupivacaine to be the only therapy which improved their symptoms. This was used as a prognostic indicator to predict which patients might respond to open nerve cryotherapy.

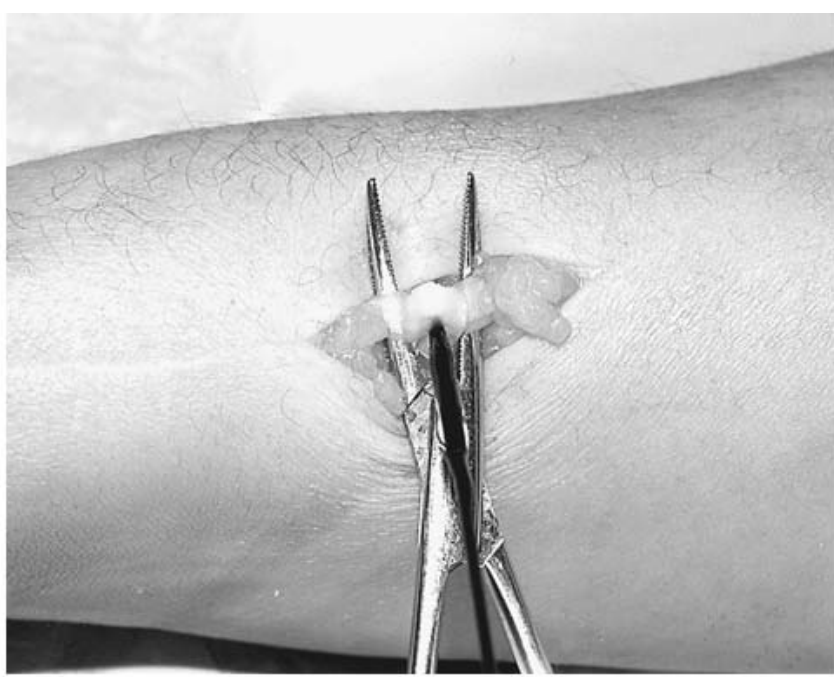

Fig. 1

Photograph showing the cryoprobe on the superficial radial nerve. 
Persistent numbness in the distribution of the treated nerve occurred in two patients for more than six months after surgery. Another had diminished sensation in the distribution of the treated nerve. All were able to return to their normal employment and activities of daily living. One of the patients with digital injuries after a burn did not respond fully to the initial cryosurgery. After a further procedure with a more extensive dissection of the digital nerve in the palm, his symptoms improved dramatically. The results are summarised in Table I.

\section{Discussion}

The use of cryosurgery for the treatment of chronic pain following damage to nerves of the upper limb shows promise. The SRN is often resistant to normal methods of pain management and cryosurgery appears to offer the prospect of benefit. Although four of our six patients showed full recovery two had a residual anaesthetic area although losing their pain. This aspect of the treatment needs to be clearly explained to patients before operation, although regeneration of the nerve should be the normal occurrence.

It is important to take a careful clinical history and examination in these patients. The use of discrete local anaesthetic blocks has been used previously to delineate the territory of a cutaneous nerve. ${ }^{12}$ The use of local anaesthetic blockade is important to confirm the diagnosis and to ensure that cryosurgery is the appropriate management.

The use of an open operation rather than a percutaneous technique for identification of the nerve is essential. This is especially important in the area of the SRN the innervation of which can be overlapped by the lateral antebrachial cutaneous nerve. ${ }^{13}$ The open technique allows accurate identification of the nerve with minimal damage to local tissue. In one patient who required a second operation, a wider view of the nerve improved the result.

We recommend open cryosurgery for cutaneous nerves of the upper limb with a chronic pain syndrome. This technique aids pain relief in a difficult clinical area.

No benefits in any form have been received or will be received from a commercial party related directly or indirectly to the subject of this article.

\section{References}

1. Dellon AL, MacKinnon SE. Treatment of the painful neuroma by neuroma resection and muscle implantation. Plast Reconstr Surg 1986;77:427-36.

2. Goldstein SA, Sturim HS. Intraosseous nerve transposition for treatment of painful neuromas. J Hand Surg [Am] 1985;10:270-4.

3. Dellon AL, MacKinnon SE. Susceptibility of the superficial sensory branch of the radial nerve to form painful neuromas. J Hand Surg [Br] 1984;9:42-5.

4. Korpan NN. Hepatic cryosurgery for liver metastases: long-term follow-up. Ann Surg 1997;225:193-201.

5. Chin JL, Downey DB, Mulligan M, Fenster A. Three-dimensional transrectal ultrasound guided cryoablation for localized prostate cancer in nonsurgical candidates: a feasibility study and report of early results. J Urology 1998;159:910-4.

6. Barnard D, Lloyd J, Evans J. Cryoanalgesia in the management of chronic facial pain. J Maxillofac Surg 1981;9:101-2.

7. Zakrzewska JM, Nally FF. The role of cryotherapy (cryoanalgesia) in the management of paroxysmal trigeminal neuralgia: a six year experience. Br J Oral Maxfac Surg 1988;26:18-25.

8. Rees RT, Rowson JE. Two new retractors for use in cryotherapy. $\mathrm{Br}$ J Oral Maxfac 1997;35:199-200.

9. Hodor L, Barkal K, Hatch-Fox LD. Cryogenic denervation of the intermetatarsal space neuroma. J Foot Ankle Surg 1997;36:311-4.

10. Barnard D. Cryosurgery of nerve. In: Bradley PF, ed. Cryosurgery of the maxillofacial region. Vol. II. Boca Raton, Florida: CRC Press, 1986:93-118.

11. Deleo JA, Coombs DW. Autotomy and decreased spinal substance $P$ following peripheral cryogenic nerve lesion. Cryobiology 1991;28:460-6.

12. Mackinnon S, Dellon AL. Results of treatment of the recurrent dorsoradial wrist neuromas. Ann Plast Surg 1987;19:54-61.

13. Mackinnon S, Dellon AL. The overlap pattern of the lateral antebrachial cutaneous nerve and the superficial branch of the radial nerve. J Hand Surg [A] 1985;10:522-6. 